Article

\title{
Assessment of Steel Subjected to the Thermomechanical Control Process with Respect to Weldability
}

\author{
Jacek Górka \\ Welding Department, Silesian University of Technology, Konarskiego 18A, 44-100 Gliwice, Poland; \\ jacek.gorka@polsl.pl
}

Received: 24 January 2018; Accepted: 7 March 2018; Published: 9 March 2018

\begin{abstract}
The study is concerned with the assessment of the weldability of steel S700MC subjected to the thermomechanical control process (TMCP) and precipitation hardening and characterised by a high yield point. Appropriate mechanical and plastic properties of steel S700MC were obtained using the thermomechanical control process through precipitation, solution, and strain hardening as well as by using grain-refinement-related processes. Constituents responsible for the hardening of steel S700MC include $\mathrm{Ti}, \mathrm{Nb}, \mathrm{N}$, and $\mathrm{C}$. The hardening is primarily affected by $(\mathrm{Ti}, \mathrm{Nb})(\mathrm{C}, \mathrm{N})$-type dispersive precipitates sized from several nanometres to between ten and twenty nanometres. The welding process considerably differs from TMCP conditions, leading to the reduction of plastic properties both in the heat-affected zone (HAZ) and in the weld area. This study demonstrates that in cases of TMCP steels, where the effect of precipitation hardening is obtained through titanium and niobium hardening phases, the carbon equivalent and phase transformation $\gamma-\alpha$ cannot constitute the basis of weldability assessment. The properties of welded joints made from the above-named group of steels are primarily affected by the stability of hardening phases, changes in their dispersion, and ageing processes. The most inferior properties were identified in the high-temperature and coarse-grained HAZ area, where the nucleation of hardening phases in the matrix and their uncontrolled reprecipitation in the fine-dispersive form lead to a sharp decrease in toughness.
\end{abstract}

Keywords: weldability; TMCP steel; HAZ

\section{Introduction}

The mechanical properties and the quality of products made of low-alloy fine-grained steels strongly depend on their microstructure, controlled through the use of appropriate thermomechanical processing. The thermomechanical control process (TMCP) is a technological process where intended changes in structure and properties of metallic materials result from the combined effect of plastic and heat treatment [1-6]. As regards temperature at which plastic straining takes place, the thermomechanical control process can be divided into high- and low-temperature thermomechanical processes. If the process involves multistage straining, it is referred to as the combined thermomechanical control process constituting the basis of thermomechanical rolling. If the process involves straining with austenite recrystallisation following successive strains, it is referred to as the thermomechanical control process constituting the basis of rolling with controlled recrystallisation. The possibility of controlling microstructural transformations results from the appropriate selection and adjustment of steelmaking conditions including heating, straining, and cooling. The ultimate structure depends on the chemical composition of steel and the cycle of the thermomechanical control process. The obtainment of a fine-grained structure is closely related to the structure of austenite, formed during hot working. The proper course of the thermomechanical control process should involve thermally 
activated phenomena taking place both before and after hot plastic straining. Recommendations found in scientific publications concerned with the welding of steels subjected to the thermomechanical control process are only related to filler metals; hydrogen reduction in welds through the use of low-hydrogen welding processes; and the reduction of preheating temperature, which should be between $50{ }^{\circ} \mathrm{C}$ and $80{ }^{\circ} \mathrm{C}$ lower than that applied in relation to normalised and toughened steels and should not exceed $100{ }^{\circ} \mathrm{C}$ [7-13]. Most scientific publications about the weldability of steels subjected to the thermomechanical control process are concerned with materials characterised by a yield not exceeding $460 \mathrm{MPa}$. These publications demonstrate that, because of lower contents of alloying components (particularly carbon), steels subjected to the thermomechanical control process are significantly less susceptible to hardening in the heat-affected zone (HAZ) in comparison with normalised steels. The HAZ of steels subjected to the thermomechanical control process contains a narrow softened area characterised by hardness lower than that of the base material and by slightly inferior mechanical properties. The authors state that the narrow width of this area does not significantly affect the mechanical properties of welded joints. However, it appears that, particularly in cases of steels characterised by a high yield point, this area could develop sensitisation to brittle and fatigue cracking and the reduction of plastic properties [13-17]. In the initial state, steels subjected to the thermomechanical control process have a fine-grained structure additionally hardened through straining. Rolling parameters including temperature, rolling reduction, and a cooling rate are adjusted to the kinetics of the precipitation of intermetallic phases of microalloying elements used in steels. Welding can disturb the course of the above-named processes, which might lead to the uncontrolled precipitation of MX-type phases. In addition, an excessively high amount of nitrogen in the base material accompanied by insufficient content of elements bonding free nitrogen (i.e., aluminium and, in particular, titanium) could lead to ageing, deteriorating the weldability of steel [18]. In cases of steels subjected to the thermomechanical control process, particularly those having a high yield point (700 $\mathrm{MPa})$, the obtainment of welds characterised by properties similar to those of welded materials (Rm, $\mathrm{KV}$ ) requires the use of filler metals having higher contents of alloying components than those present in the base material, which, in turn, might entail an increase in the carbon equivalent and result in the deterioration of welding properties $[19,20]$. There are no detailed studies concerning the welding and properties of welds and HAZ areas subjected to the thermomechanical control process. It should be noted that the welding thermal cycle significantly differs from the classical cycle of thermomechanical control process. The welding thermal cycle is accompanied by the dissolution of carbide and nitride precipitates in austenite, whereas fast cooling is responsible the supersaturation of solid solution $\alpha$ with microalloying elements, carbon, and nitrogen and/or their uncontrolled precipitation.

\section{Experimental Section}

The study aimed to assess the weldability of $10 \mathrm{~mm}$ thick TMCP steel S700MC (Table 1). The following welding processes were performed:

> MAG (Metal Active Gas) welding using a G Mn4Ni1,5CrMo $1.2 \mathrm{~mm}$ diameter solid wire and an M21 active shielding gas;

> MAG welding using a T Mn2NiCrMo $1.2 \mathrm{~mm}$ diameter flux-cored wire and an M21 active shielding gas;

$>$ Argon-shielded TIG (Tangsten Inert Gas) welding using an MT-NiMoCr 3 mm diameter solid wire;

$>\quad$ Submerged arc welding under an OK Flux 10.61 low-hydrogen flux, using an S Mn3NiMo1 $3.2 \mathrm{~mm}$ diameter solid wire;

> Laser beam welding using a TruDisk 12002 disc laser. 
Table 1. Actual chemical composition of original steel S700 MC.

\begin{tabular}{ccccccccccc}
\hline \multicolumn{10}{c}{ Chemical Composition, $\%$} \\
\hline $\mathbf{C}$ & $\mathbf{M n}$ & $\mathbf{S i}$ & $\mathbf{S}$ & $\mathbf{P}$ & $\mathbf{A l}$ & $\mathbf{N b}$ & $\mathbf{T i}$ & $\mathbf{V}$ & $\mathbf{N} *$ & $\mathbf{C e}$ \\
\hline 0.056 & 1.68 & 0.16 & 0.005 & 0.01 & 0.027 & 0.044 & 0.12 & 0.006 & 72 & 0.33 \\
\hline
\end{tabular}

${ }^{*} \mathrm{~N}$ amount expressed in ppm; the nitrogen content was measured using the high-temperature extraction method.

MAG welding is often used in the production processes of civil engineering and shipbuilding, and for the production of drilling platforms (a relatively cheap and efficient method). The TIG method is used primarily for the qualification of remelting layers and repair welding (high quality, high metallurgical purity).

The tests of $10 \mathrm{~mm}$ thick plates of steel S700MC revealed the bainitic-ferritic structure characteristic of steels subjected to the thermomechanical control process with accelerated cooling. In terms of their structure and the manner of hardening, the above-named steels differ significantly from well-known and widely described C-Mn steels containing microalloying elements. The thermomechanical control process of steel S700MC led to refinement and defects in the steel structure (Figure 1) as well as to its supersaturation with hardening constituents. The steel was subjected to precipitation, solution, and strain hardening.

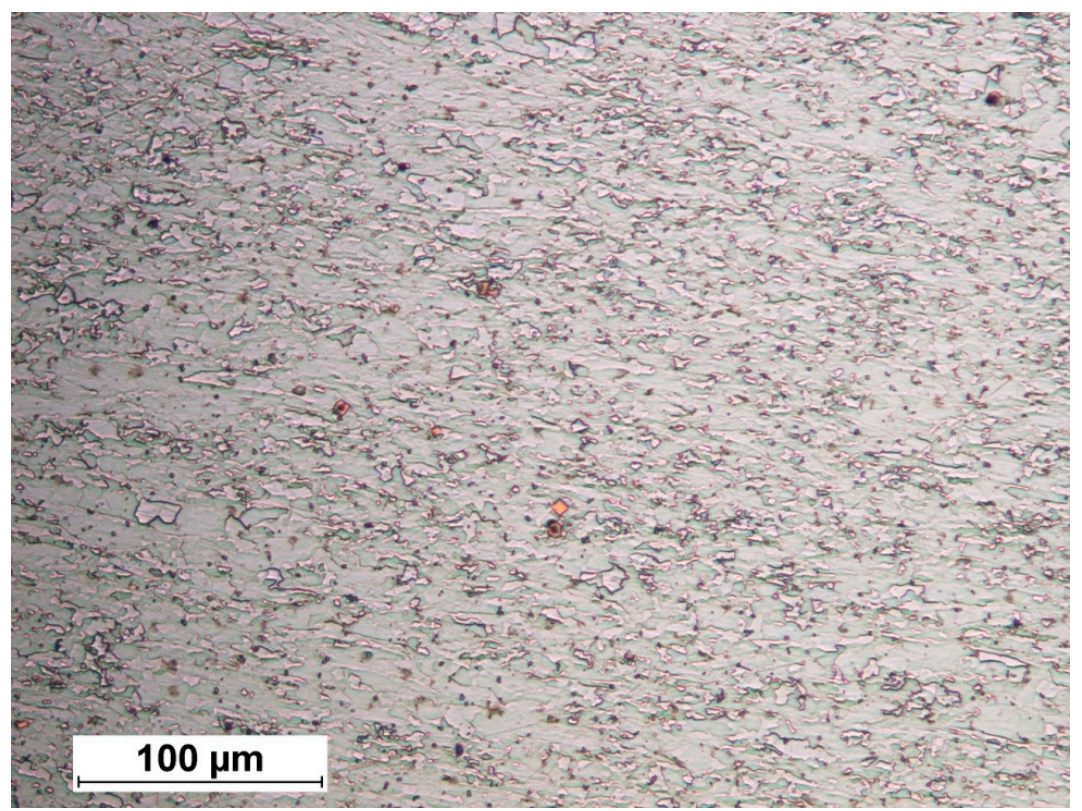

Figure 1. Structure of bainitic-ferritic steel S700MC with visible effects of plastic deformation.

Analysis from my research [17-25] justifies the statement that in cases of TMCP steels characterised by high yield point, the analysis of austenite phase transformations under conditions of welding thermal cycles and the carbon equivalent cannot constitute the sole basis of a weldability assessment. The properties of welded joints made in the above-named group of steels are primarily affected by their metastable structure, the stability of hardening phases, and changes in their dispersion and ageing processes.

The test welded joint was subjected to the following nondestructive tests: visual tests were performed on the basis of the requirements specified in the PN-EN ISO 17637:2011 standard; magnetic particle tests were performed following the guidelines referred to in the PN-EN ISO 3059:2005, PN-EN ISO 9934-2:2003, and PN-EN ISO 9934-3:2003 standards; and radiographic tests based on the PN-EN 1435 standard were performed using a CERAM 235 X-ray tube with X-ray beam diameter $d=2 \mathrm{~mm}$, 
voltage $U=180 \mathrm{kV}$, current $I=3 \mathrm{~mA}$, and intensifying screens $\mathrm{OW}$ of $-0.15 \mathrm{~mm}$. Following the nondestructive tests, the welded joint was subjected to the following destructive tests: tensile tests performed in accordance with PN-EN ISO 6892-1:2010; a face bend test of the butt weld (FBB) and a root bend test of the butt weld (RBB) performed in accordance with the PN-EN ISO 5173:2010 standard; and impact strength tests performed in accordance with PN-EN ISO 148-1:2010 using specimens with the V notch. The tests were conducted at a temperature of $-30{ }^{\circ} \mathrm{C}$ (due to industrial requirements). Because of the thickness of the plates being welded $(10 \mathrm{~mm})$ and the necessity of performing a preparatory mechanical treatment, the specimens were reduced in cross section to $7.5 \mathrm{~mm}$. The samples were extracted from the base metal, the heat-affected zone (HAZ), and the WZ (weld zone), and the specimens were etched using Nital.

The assessment of structural changes in the base material, HAZ, and weld areas was performed using light, scanning, and transmission electron microscopy (thin foils). The analysis of the chemical composition of individual micro-areas of tested microstructures was performed using an energy-dispersive X-ray spectroscopic microanalyser (SUPRA 35 EDS, Zeiss, Jena, Germany) and back-scattered electron techniques (BSE, Zeiss, Jena, Germany). The tests of thin foils were performed using a Titan 80-300 kV high-resolution scanning transmission microscope (manufactured by FEI, HR S/TEM, Hillsboro, OR, USA) provided with an XFEG electron gun featuring high-brightness Schottky field emission. The research also involved diffraction tests, where obtained diffraction patterns were solved in accordance with [26]. X-ray phase analysis was performed using an X'Pert PRO diffractometer (PANalutical, Almelo, The Netherlands) and an X'Celerator strip detector (PANalytical, Almelo, The Netherlands). A Co anode used in the tests was operated at a voltage of $40 \mathrm{kV}$ and a current of $30 \mathrm{~mA}$. The content of retained austenite in the welds of the joints made in steel S700MC was determined using the direct comparison method of Averbach and Cohen [27].

\section{Results and Discussion}

The OES-based (optical emission spectroscopic) analysis of the chemical composition of steel S700MC confirmed the consistency of the steel chemical composition with the PN EN 10149-2 standard. In the steel subjected to spectroanalysis, the content of carbon amounted to $0.056 \%$ by weight, whereas the contents of hardening microalloying elements, i.e., titanium, niobium, and vanadium, amounted to $0.12 \%, 0.044 \%$, and $0.006 \%$, respectively. The total content of microalloying elements did not exceed the allowed concentration, amounting to $0.22 \%$. The content of nitrogen, determined using the high-temperature extraction method, amounted to approximately $70 \mathrm{ppm}$. Appropriate mechanical and plastic properties of the test steel were obtained through the thermomechanical control process involving precipitation, solution, and strain hardening as well as through grain-refinement-related processes. Chemical elements responsible for the hardening of steel S700MC were Ti and Nb. Tests of thin foils performed using a transmission electron microscope revealed that the hardening of steel S700MC was primarily affected by dispersive $(\mathrm{Ti}, \mathrm{Nb})(\mathrm{C}, \mathrm{N})$-type precipitates sized from several nanometres to between ten and twenty nanometres. The precipitation hardening was mainly triggered by dispersive precipitates of several nanometres in size, precipitated in the steel (in ferrite) during cooling (Figure 2) [28-32]. Particles sized above twenty nanometres did not significantly contribute to precipitation hardening, yet they restrained the recrystallised austenite grain growth, favouring the formation of the fine-grained structure [28,33-37]. The recrystallised austenite grain growth in the test steel was primarily restrained by precipitates of globular $(\mathrm{Nb}, \mathrm{Ti}) \mathrm{C}$ carbides of approximately $10 \mathrm{~nm}$ in diameter and characterised by niobium predominance [38], precipitates of $(\mathrm{Ti}, \mathrm{Nb}) \mathrm{C}$ carbides of approximately $20 \mathrm{~nm}$ in size, and $(\mathrm{Ti}, \mathrm{Nb})(\mathrm{C}, \mathrm{N})$ precipitates of approximately $50 \mathrm{~nm}$ in size. The dual morphology of some precipitates of titanium and niobium carbonitrides (Figure 3) indicated that $\mathrm{NbC}$-type carbides were epitaxially precipitated (at high temperature) on characteristic tetragonal TiN particles, forming complex $(\mathrm{Ti}, \mathrm{Nb})(\mathrm{C}, \mathrm{N})$-type precipitates [33]. 

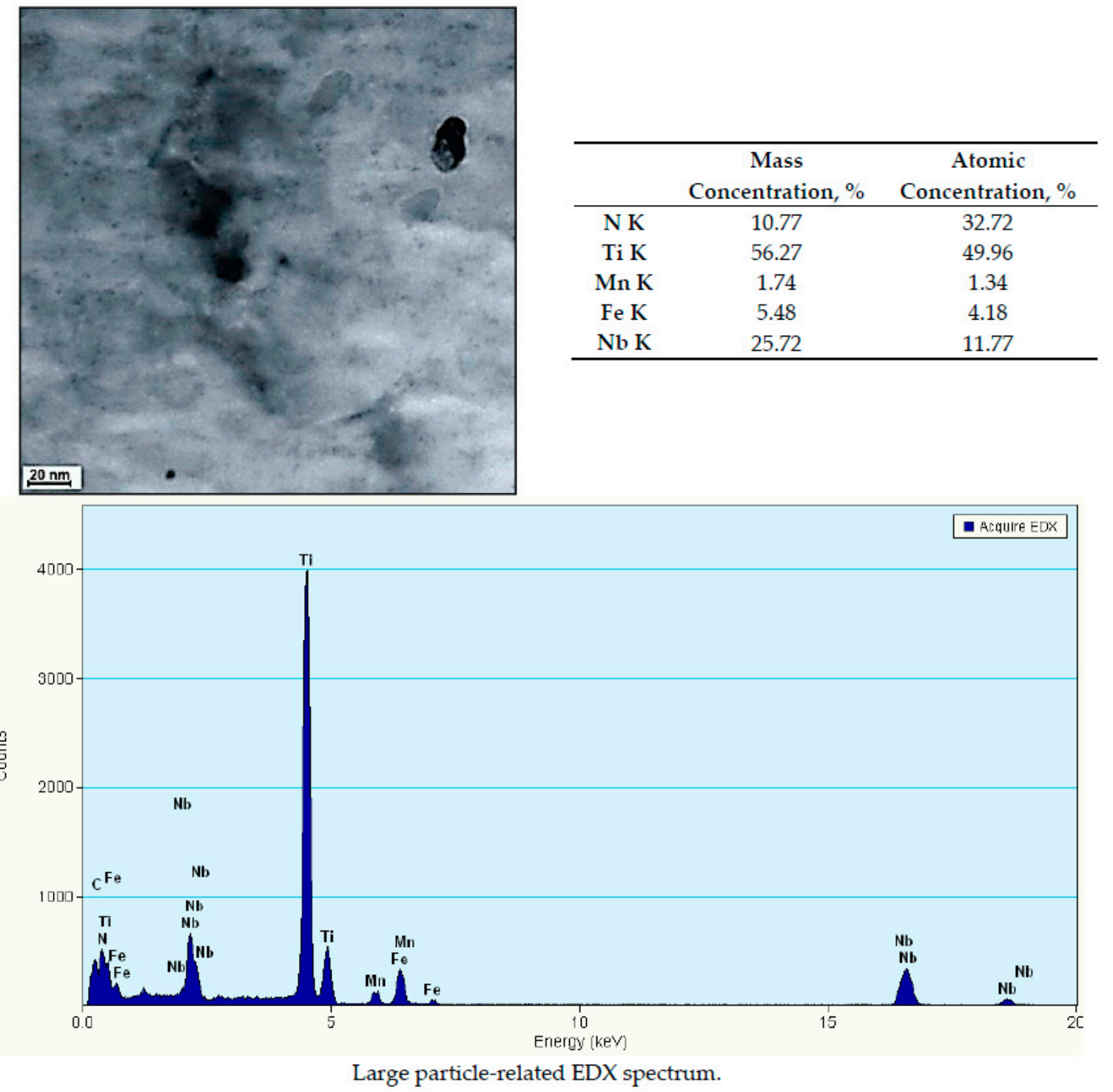

Figure 2. Precipitation of carbonitride $(\mathrm{Ti}, \mathrm{Nb})(\mathrm{C}, \mathrm{N})$ with numerous small dispersive precipitates corresponding to the hardening of steel.

The tests of the phase transformations in steel S700MC subjected to simulated thermal conditions were used to determine a CCT diagram under welding conditions along with a complementary diagram concerning changes in hardness in the function of cooling time $t_{8 / 5}$ (Figure 4). The structural transformation studies of S700MC steel were carried out on a prototype pilot bench, wherein the heating of the test samples was done using an infrared lamp. The methodology of the structural changes studies was based on the simultaneous use of three measurement methods: the dilatometric, magnetometric, and thermal analysis methods. The tests revealed that, as a function of cooling time $t_{8 / 5}$, the microstructure of steel S700MC changed as described below. Cooling time $t_{8 / 5}$ shorter than approximately $3 \mathrm{~s}$ was accompanied by martensite, whereas between $3 \mathrm{~s}$ and approximately $10 \mathrm{~s}$ it was accompanied by a mixture of martensite and bainite. Cooling time $t_{8 / 5}$ restricted within the range of approximately $10 \mathrm{~s}$ to approximately $14 \mathrm{~s}$ was accompanied by bainite, whilst cooling time $t_{8 / 5}$ exceeding $14 \mathrm{~s}$ was accompanied by the formation of ferrite. When cooling time $t_{8 / 5}$ was restricted within the range of approximately $60 \mathrm{~s}$ to approximately $200 \mathrm{~s}$, the microstructure of steel was composed by the mixture of bainite and ferrite in variable contents (Figure 5). 


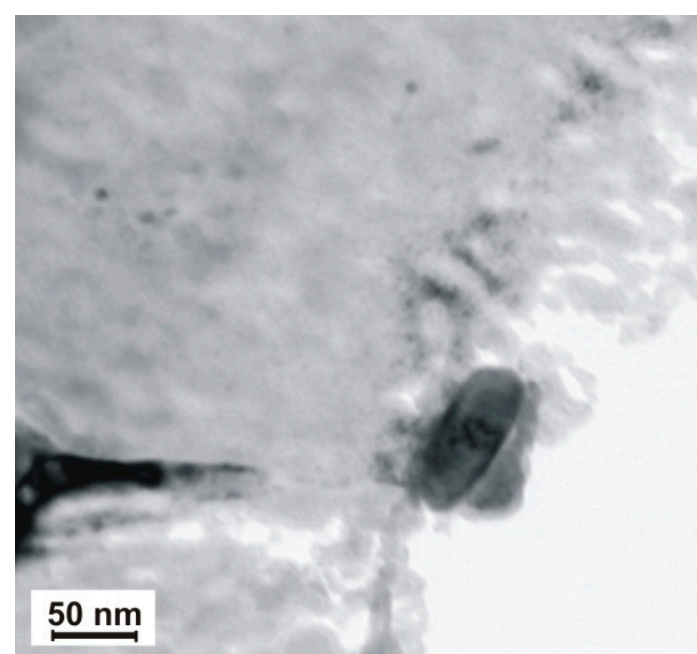

Bright field

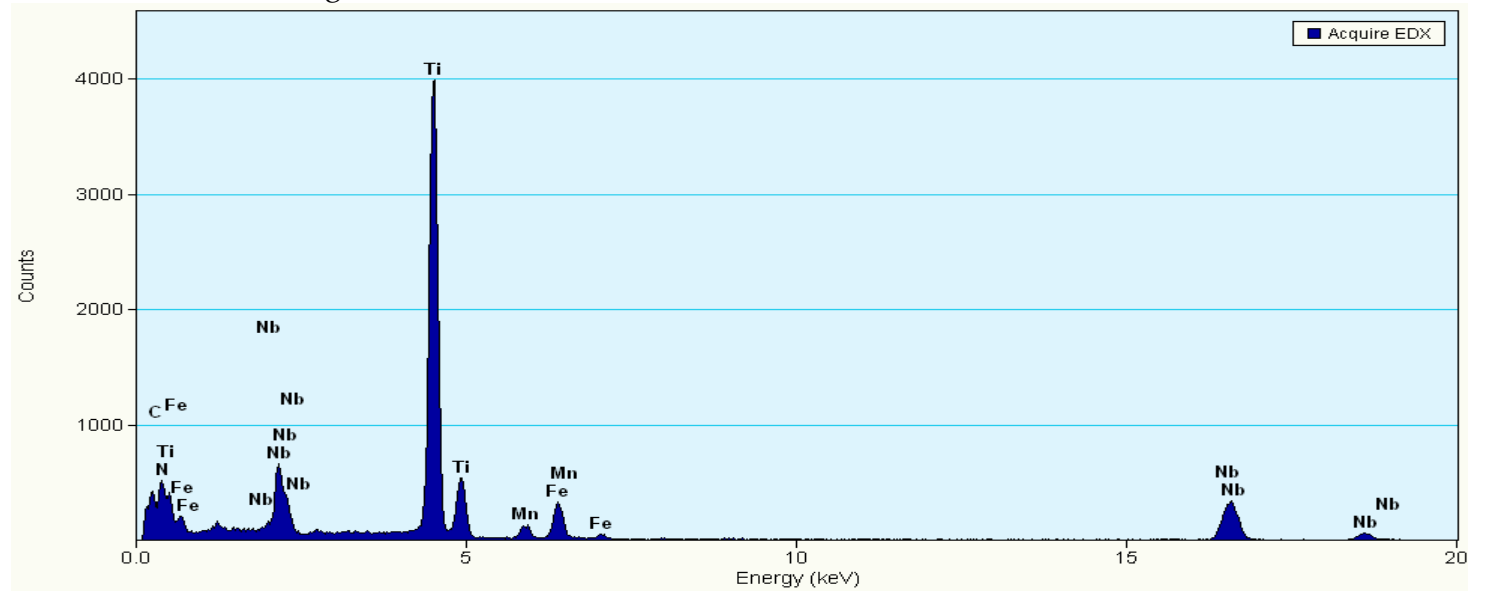

EDX spectrum

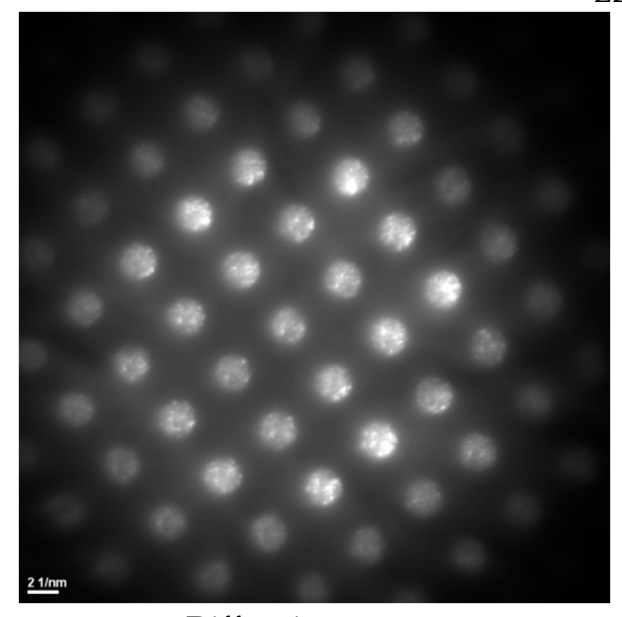

Diffraction pattern

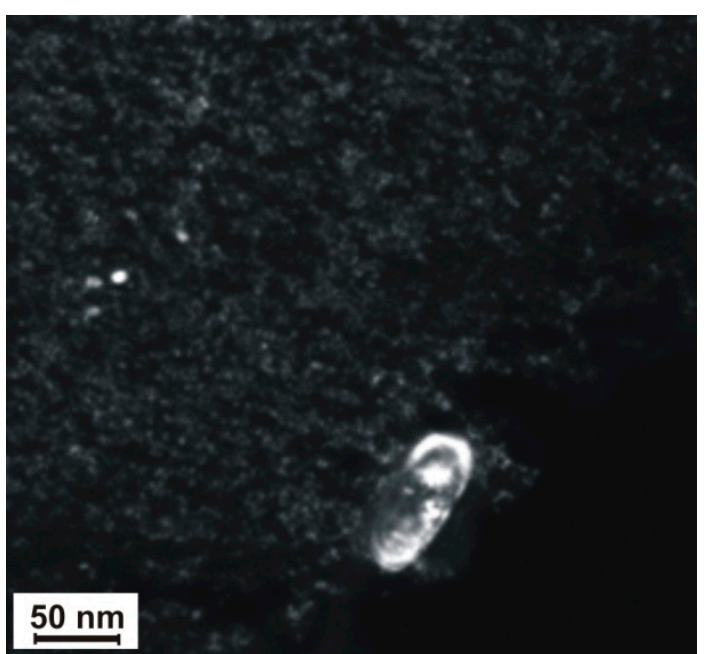

Dark field

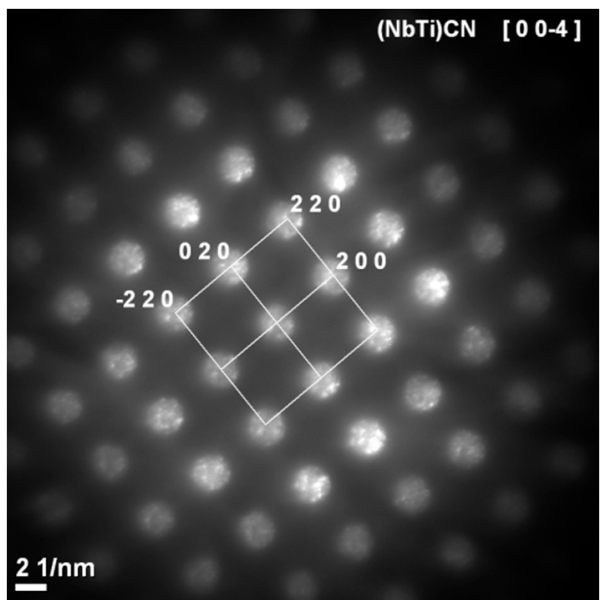

Diffraction pattern solution

Figure 3. Carbonitride $(\mathrm{Ti}, \mathrm{Nb})(\mathrm{C}, \mathrm{N})$ with small spherical precipitates responsible for the precipitation hardening of steel S700MC. 


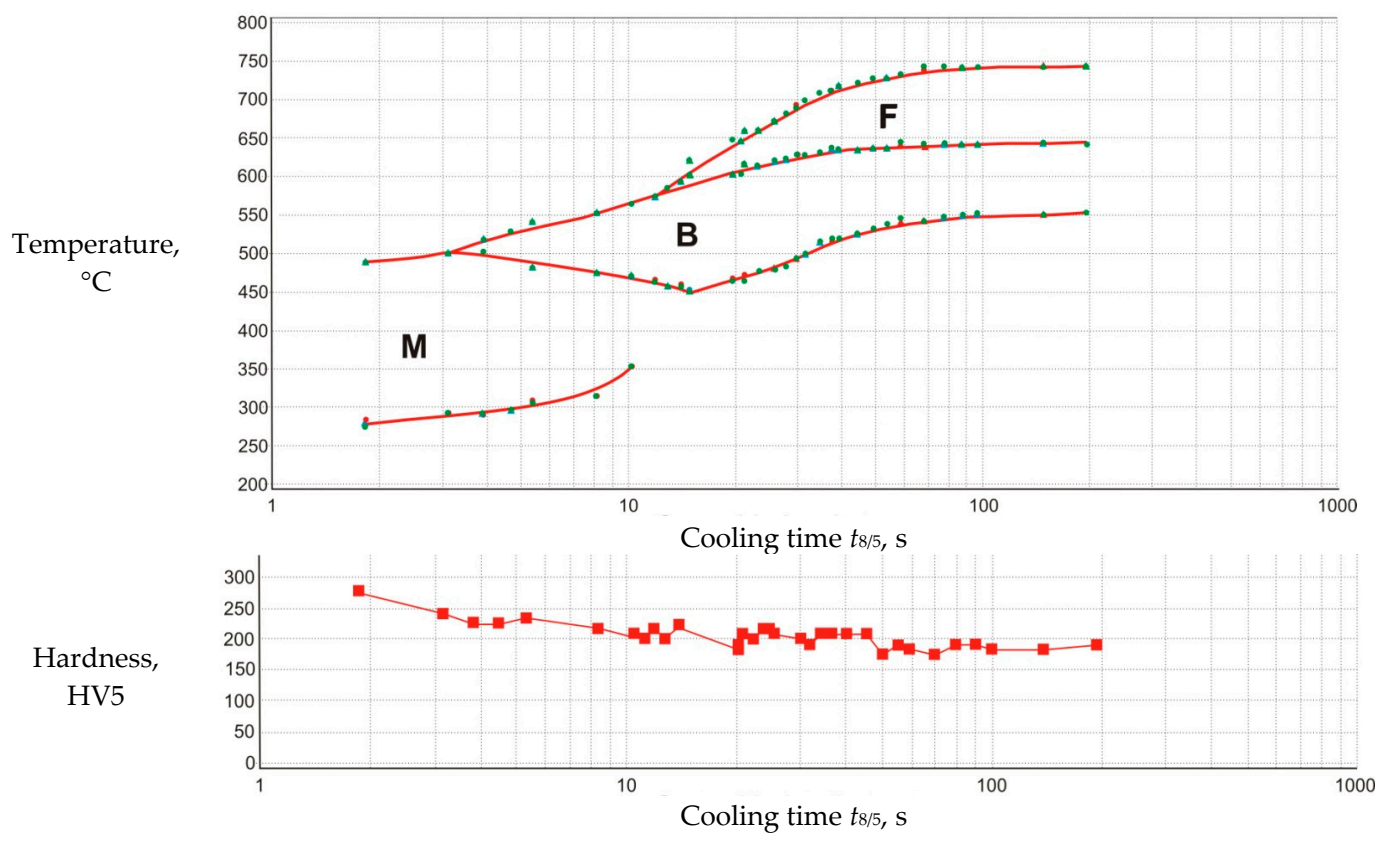

Figure 4. Chart of structural changes in the steel S700MC in terms of welding CCT-W together with complementary graph on the distribution of hardness as a function of the cooling time $t_{8 / 5}$.

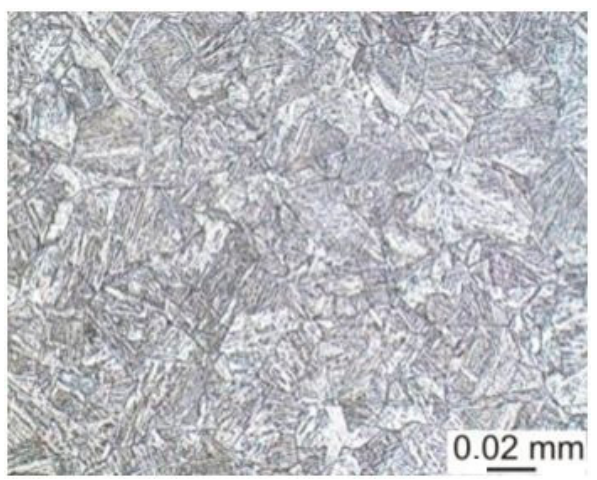

Cooling times $t_{8 / 5}=3.40 \mathrm{~s}$; martensite + bainite structure; 238 HV5

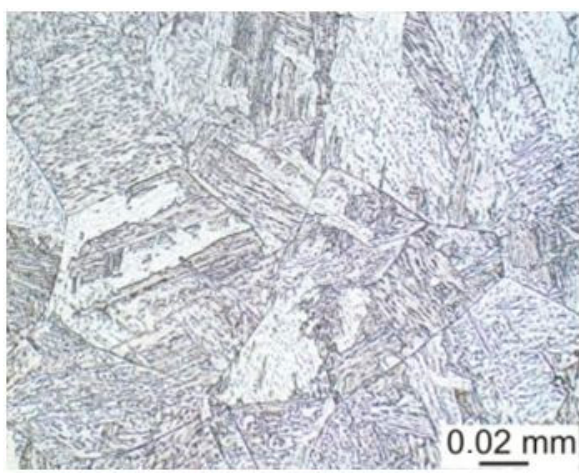

Cooling times $t_{8 / 5}=12.96 \mathrm{~s}$; bainite structure; 215 HV5

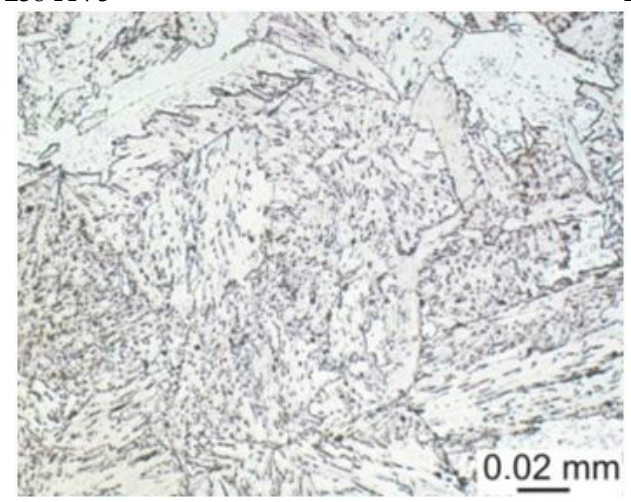

Cooling times $t_{8 / 5}=87.84 \mathrm{~s}$; ferrite + bainite structure; $192 \mathrm{HV} 5$

Figure 5. Examples of the microstructure of S700MC steel as a function of the cooling time $t_{8 / 5}$.

The obtained test results revealed that the processes related to allotropic transformation $\gamma-\alpha$ taking place in steel S700MC during cooling cannot constitute the basis for the assessment of the steel welding-related properties. According to the CCT diagram under welding conditions, steel 
S700MC underwent a martensitic transformation, yet it did not lead to an increase in hardness in relation to that of the base material. The foregoing confirms the hypothesis that carbon present in a solution only slightly contributes to the hardening of steel and is not a dominant factor in phase transformations. Steel S700MC is characterised by low hardenability because of the low concentration of unbounded carbon (approximately $0.03 \%$ ) and other alloying elements. The process of cooling is shortly followed by the formation of martensite. However, the martensite formed after cooling is a low-carbon variety, i.e., it does not decrease the steel plasticity. The hardness measurements performed within the entire range of analysed cooling times $t_{8 / 5}$ did not reveal the susceptibility of steel S700MC to cold cracking (maximum measured hardness did not exceed 270 HV5). The extension of cooling time was accompanied by a decrease in hardness, which was primarily related to an increase in the content of ferrite in the structure of the tested steel and to the grain growth. The X-ray phase analysis revealed that the base material and the weld made using the laser beam were entirely composed of phase $\alpha$. In cases of the welds made using the arc welding method (MAG, submerged arc, TIG), in addition to phase $\alpha-\mathrm{Fe}$, the weld contained a slight amount of phase $\gamma$-Fe (Figures 6 and 7). The presence of phase $\gamma$-Fe could be tied to the presence of austenitic alloying elements such as $\mathrm{Ni}$ and $\mathrm{C}$ in the weld deposit. Phase $\gamma$ is retained austenite, adversely affecting the operational properties of welded structures subjected to changing mechanical and thermal loads [38-42]. The analysis of the total intensities of diffraction maxima of X-radiation from the lattice planes of phases $\alpha$-Fe and $\gamma$-Fe of individual welded joints enabled the determination of the content of retained austenite at between $3 \%$ and $6 \%$.

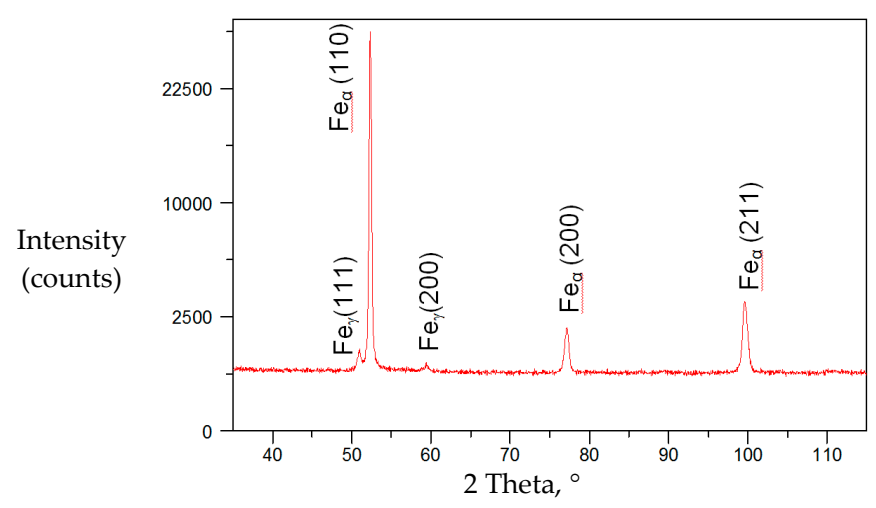

Figure 6. X-ray diffraction of the butt weld made in steel S700MC using the MAG method and a linear energy of $8 \mathrm{~kJ} / \mathrm{cm}$.

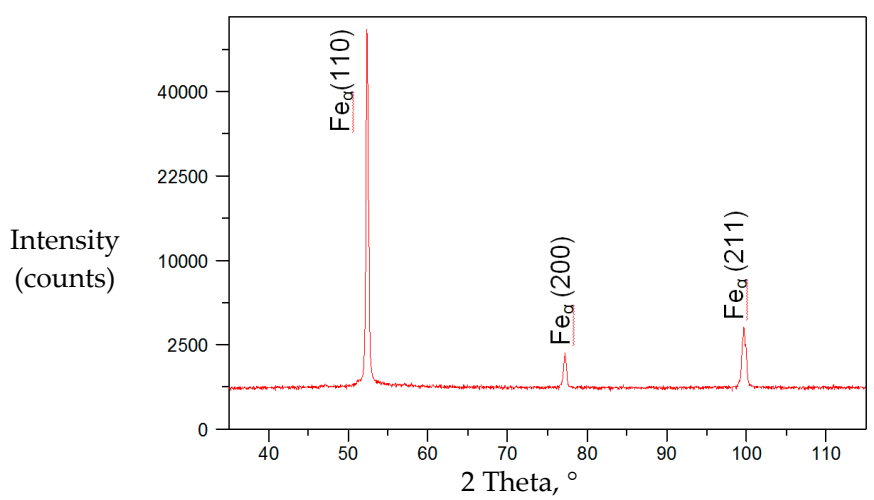

Figure 7. X-ray diffraction of the butt weld made in steel S700MC using laser beam welding and a linear energy of $5 \mathrm{~kJ} / \mathrm{cm}$. 


\section{Effect of a Welding Method and Linear Energy on the Properties of Welded Joints}

The visual and magnetic particle tests of the welded joints did not reveal the presence of surface welding imperfections, i.e., cracks, porosity, incomplete fusions, or lacks of penetration. The radiographic tests did not reveal the presence of internal welding imperfections. The welded joints satisfied the requirements of quality level B according to standard ISO 5817 and ISO 13919-1. The analysis of destructive tests involving the arc welded joints and laser welded joints revealed the significant effect of welding method and linear energy on the mechanical and plastic properties of the joints (see Table 2).

Table 2. Effect of welding and heat input on the mechanical and plastic properties of welded joints.

\begin{tabular}{|c|c|c|c|c|c|c|c|c|}
\hline \multirow{3}{*}{$\begin{array}{l}\text { Welding Method/Linear } \\
\text { Welding Energy, kJ/cm }\end{array}$} & \multicolumn{2}{|c|}{ Tensile Strength * } & \multicolumn{2}{|c|}{$\begin{array}{c}\text { Bending *, Bend } \\
\text { Angle, }{ }^{\circ}\end{array}$} & \multicolumn{4}{|c|}{$\begin{array}{c}\text { Impact Strength } \mathrm{KCV}{ }^{* *}, \mathrm{~J} / \mathrm{cm}^{2} \text { (Test } \\
\left.\text { Temperature }-30^{\circ} \mathrm{C}\right)\end{array}$} \\
\hline & \multirow{2}{*}{$R_{\mathrm{m}}, \mathrm{MPa}$} & \multirow{2}{*}{$\begin{array}{l}\text { Place of } \\
\text { Rupture }\end{array}$} & \multirow{2}{*}{$\begin{array}{l}\text { Face of } \\
\text { Weld }\end{array}$} & \multirow{2}{*}{$\begin{array}{l}\text { Root of } \\
\text { Weld }\end{array}$} & \multicolumn{2}{|c|}{ Weld } & \multicolumn{2}{|c|}{ HAZ } \\
\hline & & & & & $\begin{array}{l}\mathrm{KCV} \\
\mathrm{J} / \mathrm{cm}^{2}\end{array}$ & Fracture & $\begin{array}{l}\mathrm{KCV} \\
\mathrm{J} / \mathrm{cm}^{2}\end{array}$ & Fracture \\
\hline Laser/5 & 790 & FL & 180 & 180 & 20 & brittle & - & - \\
\hline $\mathrm{MAG}^{\mathrm{SW}} / 8$ & 860 & $\mathrm{BM}$ & 180 & 180 & 94 & mixed & 86 & mixed \\
\hline $\mathrm{MAG}^{\mathrm{CW}} / 8$ & 810 & $\mathrm{BM}$ & 180 & 180 & 79 & mixed & 66 & mixed \\
\hline TIG/10 & 812 & $\mathrm{BM}$ & 180 & 180 & 72 & mixed & 57 & mixed \\
\hline SAW /10 & 816 & $\mathrm{BM}$ & 180 & 180 & 69 & mixed & 48 & mixed \\
\hline $\mathrm{MAG}^{\mathrm{SW}} / 15$ & 760 & HAZ & 180 & 180 & 77 & mixed & 38 & brittle \\
\hline $\mathrm{MAG}^{\mathrm{CW}} / 15$ & 790 & $\mathrm{BM}$ & 180 & 180 & 71 & mixed & 41 & brittle \\
\hline SAW /15 & 797 & FL & 180 & 180 & 68 & mixed & 42 & brittle \\
\hline TIG/30 & 653 & HAZ & 180 & 180 & 63 & mixed & 35 & brittle \\
\hline $\mathrm{SAW} / 30$ & 685 & HAZ & 180 & 180 & 43 & brittle & 27 & brittle \\
\hline SAW / 40 & 637 & HAZ & 180 & 180 & 29 & brittle & 17 & brittle \\
\hline
\end{tabular}

${ }^{*}$ Result the average of two measurements; ${ }^{* *}$ result the average of three measurements; BM: base material; WZ: weld zone; HAZ: heat affected zone; SW: solid wire; CR: cored wire.

Tensile tests were performed in accordance with PN-EN ISO 6892-1:2010 using a ZWICK/ROELL Z 330RED (Zwick Roell, Ulm, Germany) testing machine and specimens sampled in accordance with PN-EN ISO 4136:2011 (dimensions of the sample: $300 \mathrm{~mm} \times 35 \mathrm{~mm} \times 10 \mathrm{~mm}$ ). A face bend test of the butt weld (FBB) and a root bend test of the butt weld (RBB) were performed in accordance with the PN-EN ISO 5173:2010 standard (dimensions of the sample: $300 \mathrm{~mm} \times 20 \mathrm{~mm} \times 10 \mathrm{~mm}$ ). The bend tests were performed using a testing machine with an additional module enabling the performance of bend tests involving the use of a bending mandrel with a diameter of $30 \mathrm{~mm}$. The distance between the rollers was set at $60 \mathrm{~mm}$. To identify the position of the weld axis, the faces of the specimens were etched using Adler's reagent. The increase in welding energy from $8 \mathrm{~kJ} / \mathrm{cm}$ (MAG welding with solid wire and cored wire) to $40 \mathrm{~kJ} / \mathrm{cm}$ (submerged arc welding) causes a drop in tensile strength from 860 to $640 \mathrm{MPa}$. At higher welding energies, the tensile strength decreases in the HAZ area below the strength of the parent material. This is mainly related to the increase in the proportion of ferrite in the structure and grain growth in this area. This was confirmed by hardness measurements which showed that in the HAZ area of welded joints of S700MC steel, softening occurs (reduction of hardness in relation to the hardness of the native material). The higher the linear welding energy, the greater the softening, and, consequently, the lower the strength properties. When welding with very high linear energies ( 30 and $40 \mathrm{~kJ} / \mathrm{cm}$ ), the hardness also reaches a value of $220 \mathrm{HV} 5$ in the weld area, due to coarse crystallisation (Figure 8).

Microscopic tests of the joints revealed changes in the microstructure of the weld and HAZ areas in comparison with that of the base material. Both in the weld and HAZ of each test joint, the plastic strain effect in the form of grains elongated in the direction of rolling, obtained during the production of the plates, was eliminated. The weld area structure was dendritic and composed of bainite and ferrite lamellas formed out of retained austenite grains. The HAZ in each of the test joints contained a fine-grained microstructure visibly dominated by ferrite (Figure 9). 


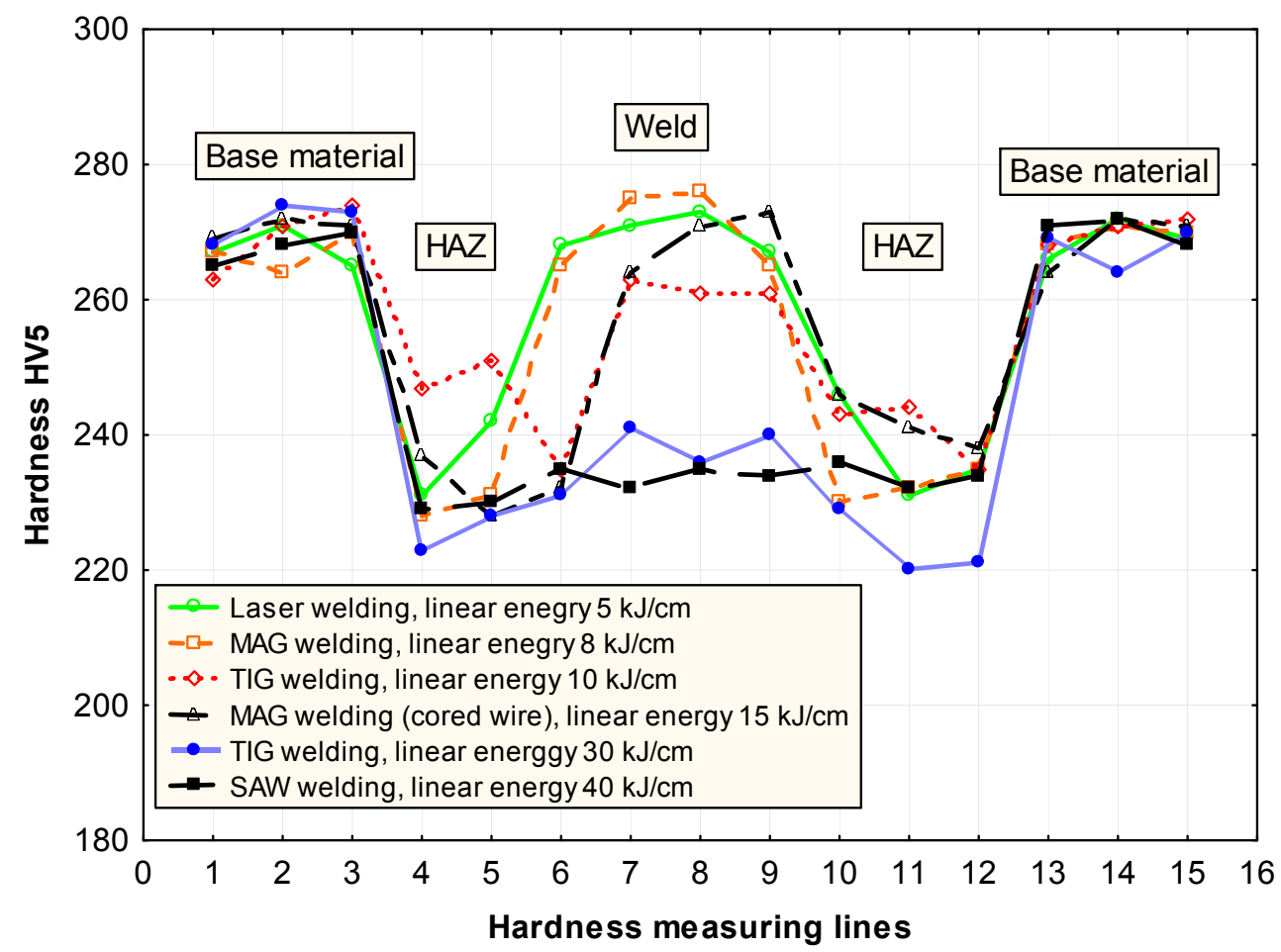

Figure 8. Effect of welding method and input heat on the hardness on the cross section of the S700MC welded joints.

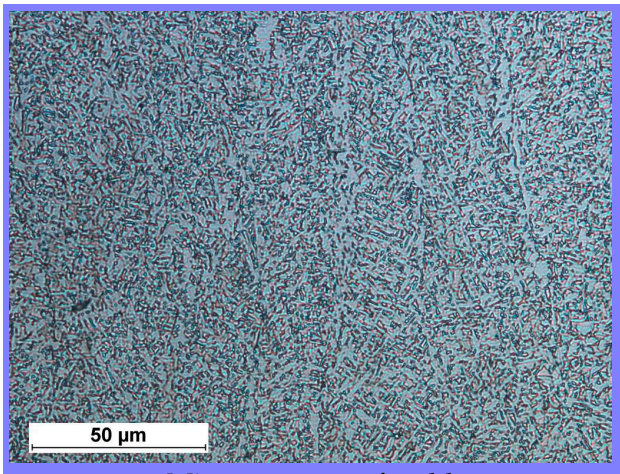

Microstructure of weld

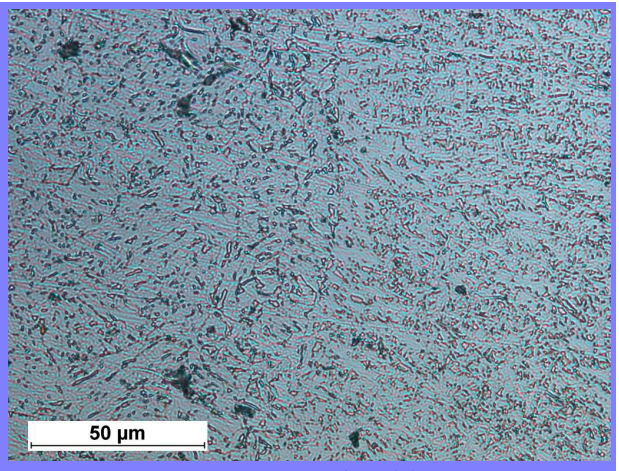

Microstructure of weld zone

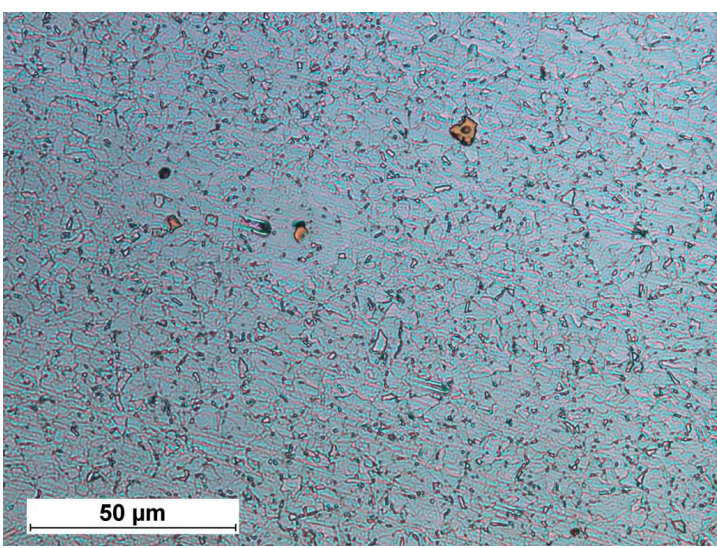

Microstructure of fine-grained part of the HAZ

Figure 9. Microstructure of the MAG welded joint. 
The toughness of the arc welded joints was affected not only by linear energy but also by the welding method (content of the base material in the weld). During arc welding performed using low linear energy, the toughness of the weld and that of HAZ were high (Figure 10). An increase in welding linear energy above $15 \mathrm{~kJ} / \mathrm{cm}$ resulted in a significant decrease in toughness in the HAZ area.

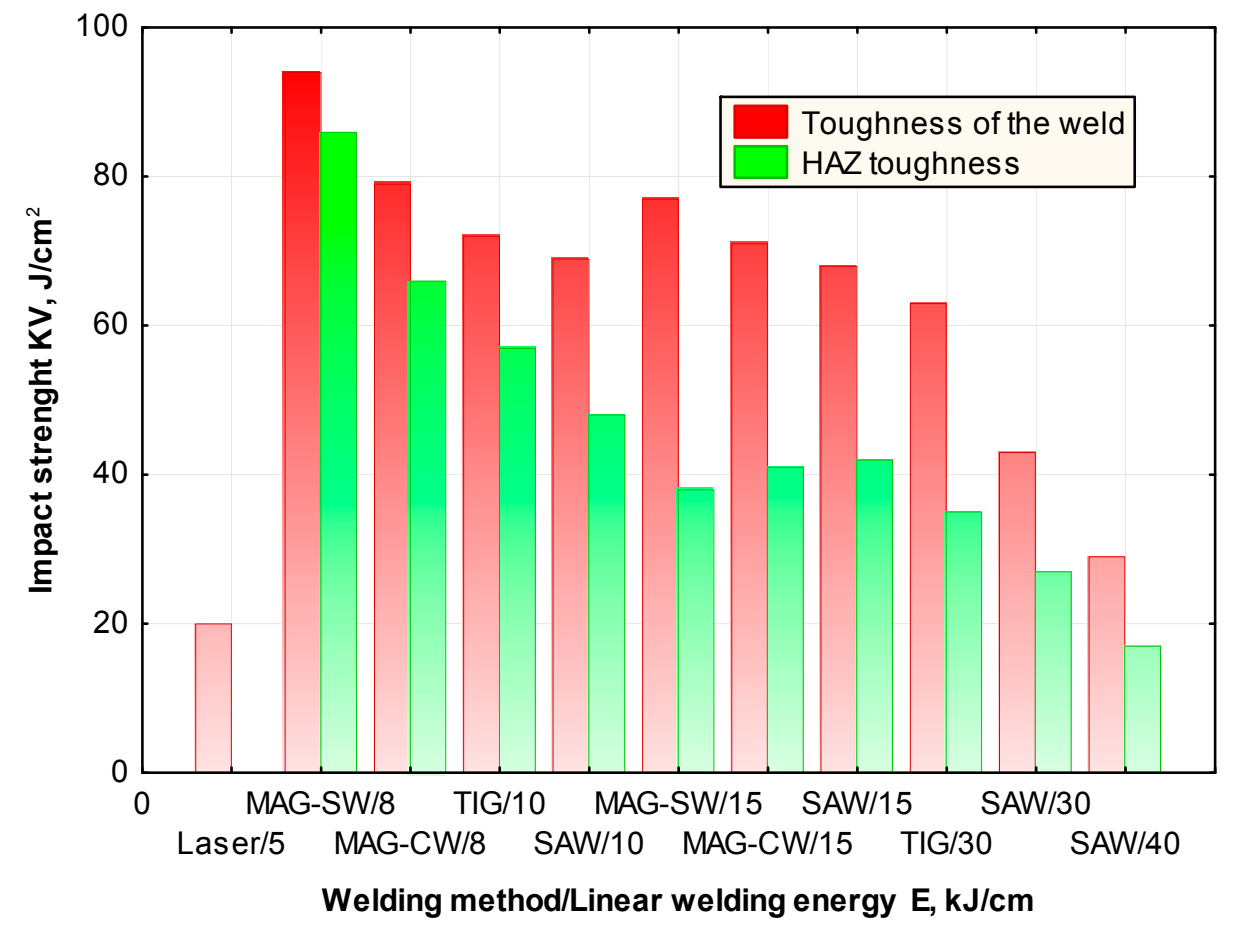

Figure 10. Effect of welding method and heat input on the toughness of the welded joints made of steel S700MC.

The high HAZ toughness values in the joints welded using low welding linear energy (below $15 \mathrm{~kJ} / \mathrm{cm}$ ) were triggered by the coagulation of $(\mathrm{Ti}, \mathrm{Nb})(\mathrm{C}, \mathrm{N})$-type hardening precipitates (Figure 11) as well as by the related decay of precipitation hardening and recrystallisation processes. The increase in welding linear energy, particularly in the high-temperature HAZ, was accompanied by the partial dissolution of hardening constituents in the matrix and, during cooling, by the uncontrolled precipitation of the above-named constituents in the form of fine-dispersive particles sized from several nanometres to between ten and twenty nanometres (Figure 12), responsible for hardening and increased dislocation density, leading to reduced toughness.

The microscopic observations revealed that during arc welding, carbonitride precipitates (of several $\mu \mathrm{m}$ in size) dissolved entirely in the weld area, which, in cases of longer crystallisation times (higher values of welding linear energy), could result in significant precipitation hardening and lead to the reduction of weld toughness. Cooling was accompanied by the lack of appropriate conditions enabling the controlled reprecipitation of fine-dispersive carbides and carbonitrides $(\mathrm{Ti}, \mathrm{Nb})$ in the weld. During laser welding, in spite of low values of welding linear energy, toughness was very low (below $20 \mathrm{~J} / \mathrm{cm}^{2}$ ). In welds made using the laser welding method without the filler metal, the contents of $\mathrm{Ti}$ and $\mathrm{Nb}$ were significantly higher than those in the welds made using the arc welding method (the filler metal did not contain $\mathrm{Ti}$ or $\mathrm{Nb}$ ). The significant content of the hardening phases in the weld during cooling resulted in considerable precipitation hardening through fine-dispersive $(\mathrm{Ti}, \mathrm{Nb})(\mathrm{C}, \mathrm{N})$-type precipitates of several $\mathrm{nm}$ in size, precipitated next to greater $(\mathrm{Ti}, \mathrm{Nb}) \mathrm{N}$ and $\mathrm{TiC}$ particles of $100 \mathrm{~nm}$ in size (Figure 13). The foregoing led to increased dislocation density and reduced plastic properties. 


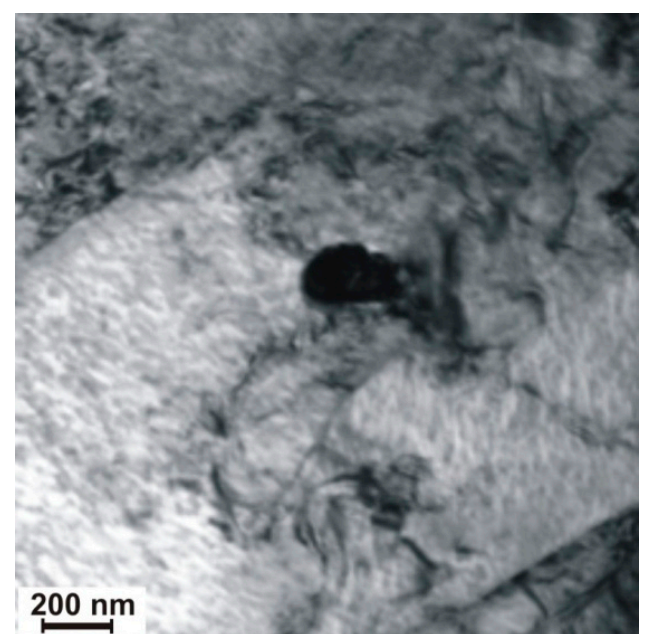

$200 \mathrm{~nm}$

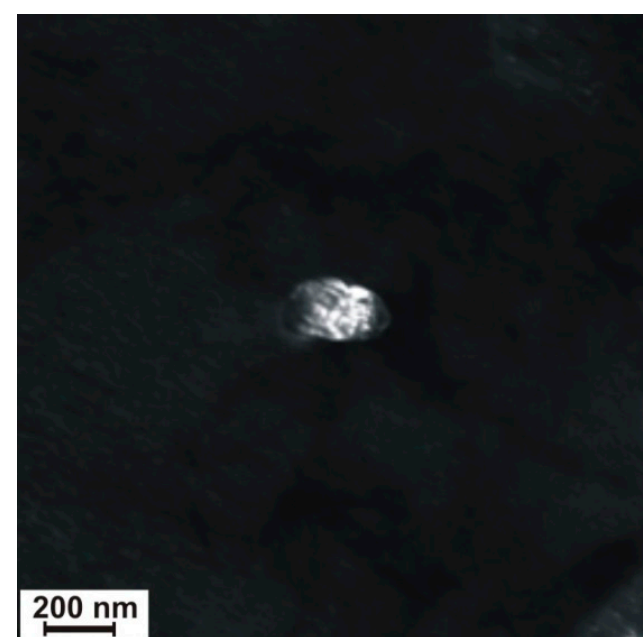

Dark field

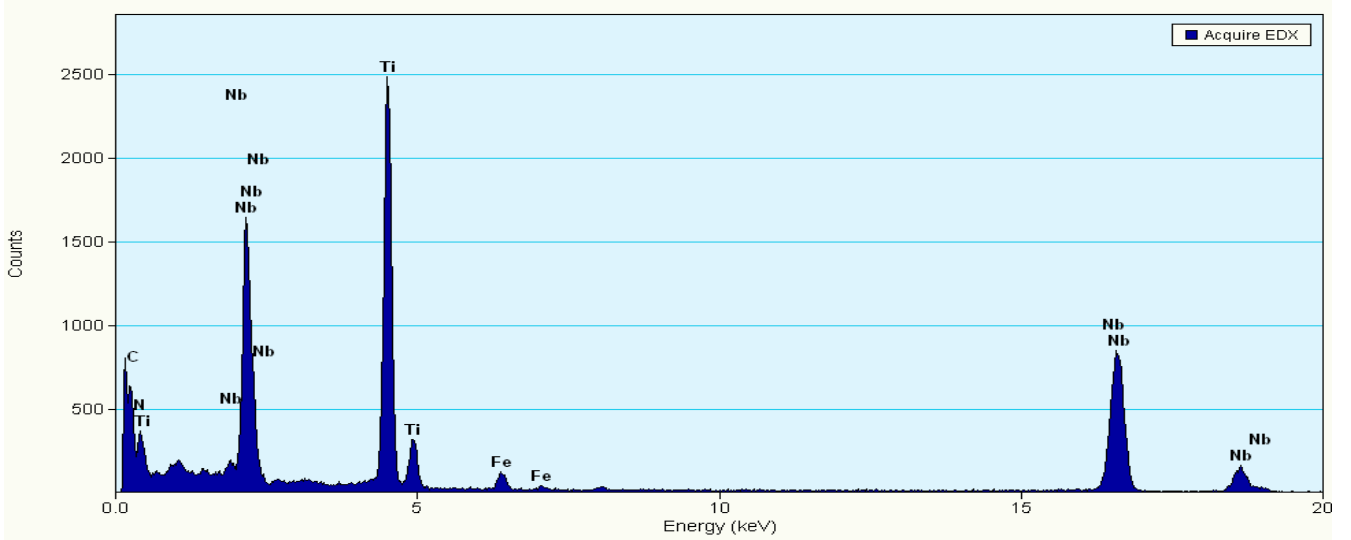

EDX spectrum

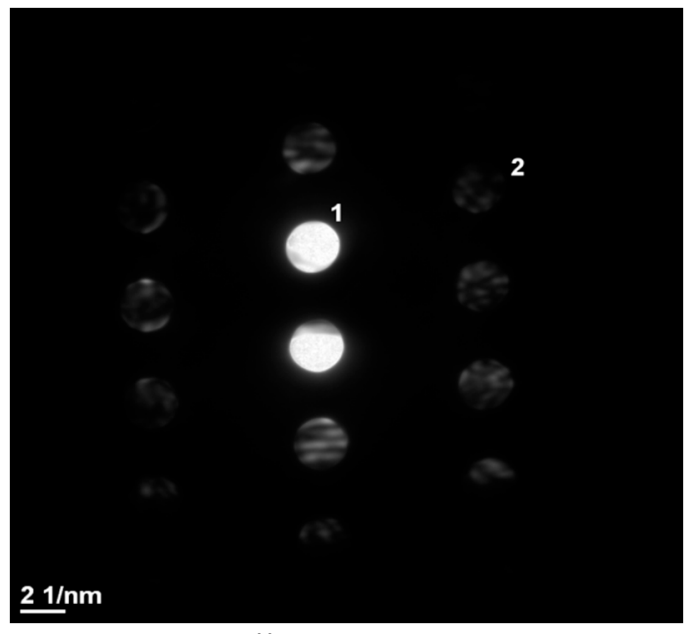

Diffraction pattern

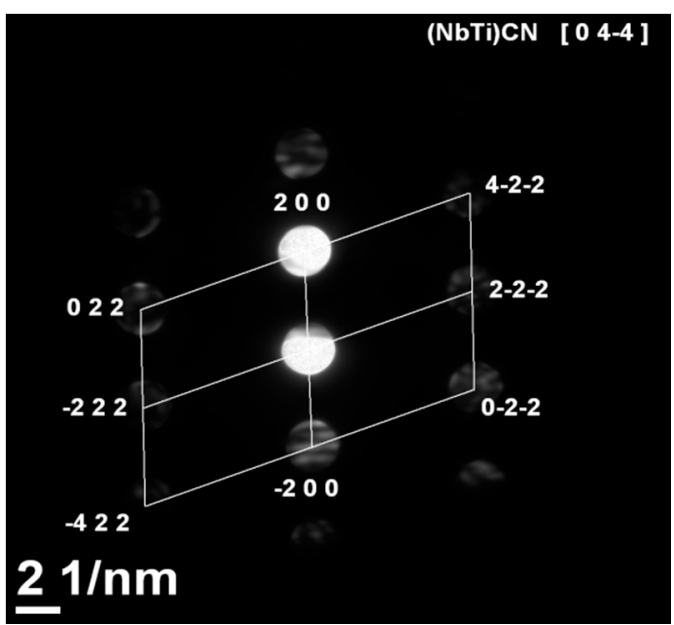

Diffraction pattern solution

Figure 11. Coagulated separation precipitation of carbonitride $(\mathrm{Ti}, \mathrm{Nb})(\mathrm{C}, \mathrm{N})$ in the HAZ of steel S700MC steel; welding was performed using the MAG method, a flux-cored wire, and a linear energy of $8 \mathrm{~kJ} / \mathrm{cm}$. 


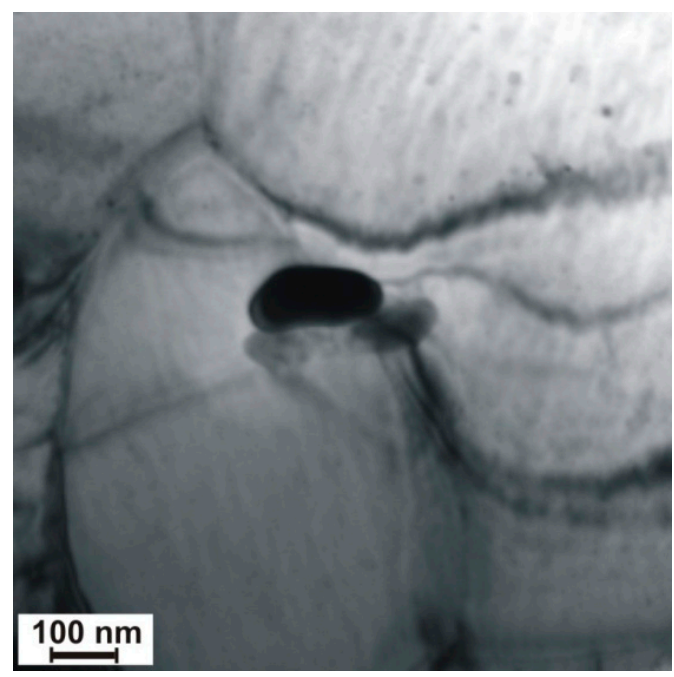

Bright field

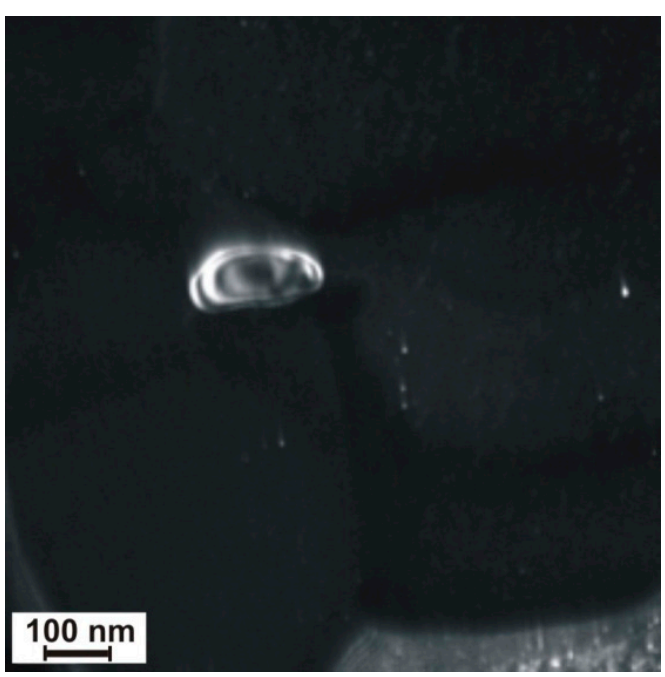

Dark field

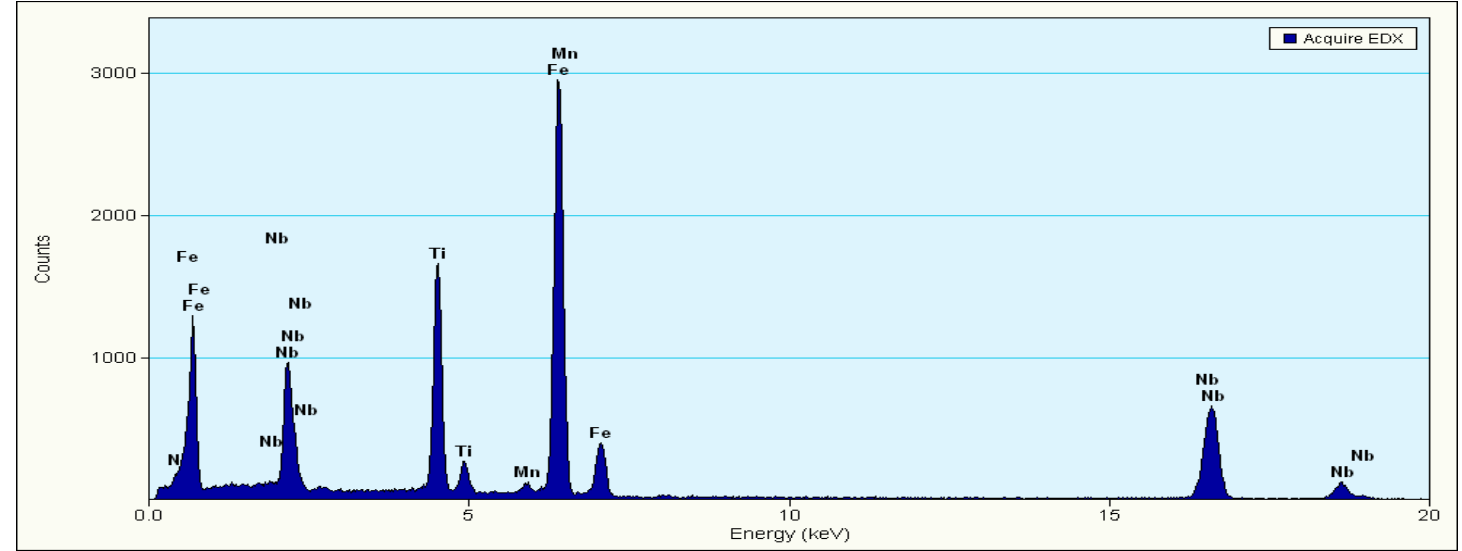

EDX spectrum

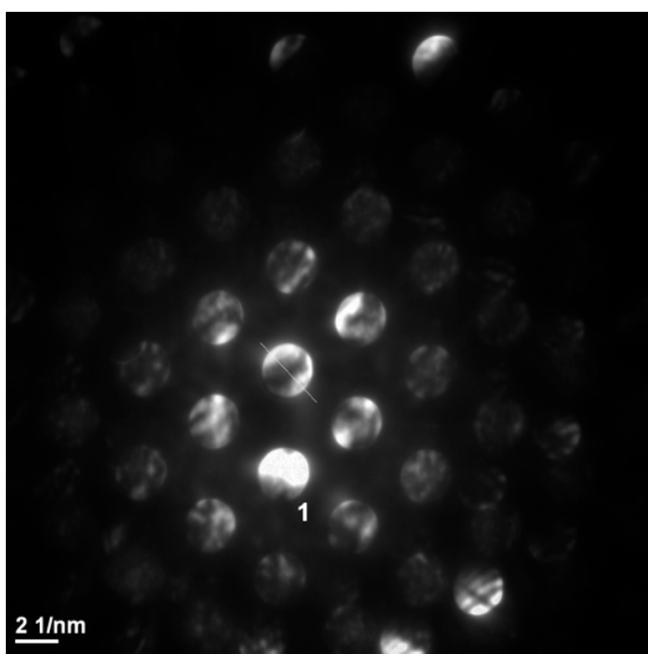

Diffraction pattern

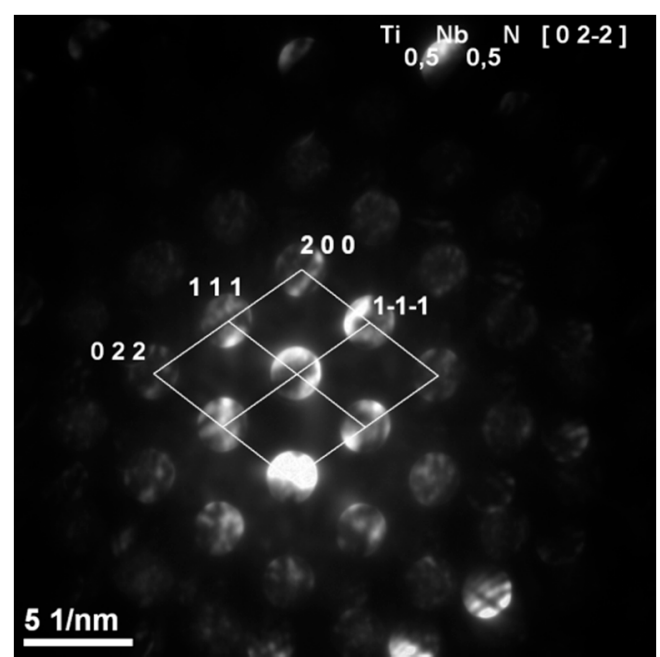

Diffraction pattern solution

Figure 12. Precipitation of nitride $(\mathrm{Ti}, \mathrm{Nb}) \mathrm{N}$ along with a number of spherical precipitates with high dispersion of dislocations in a plastically deformed matrix surrounding the HAZ of steel S700MC; the welding process was performed using the TIG method and a linear energy of $30 \mathrm{~kJ} / \mathrm{cm}$. 

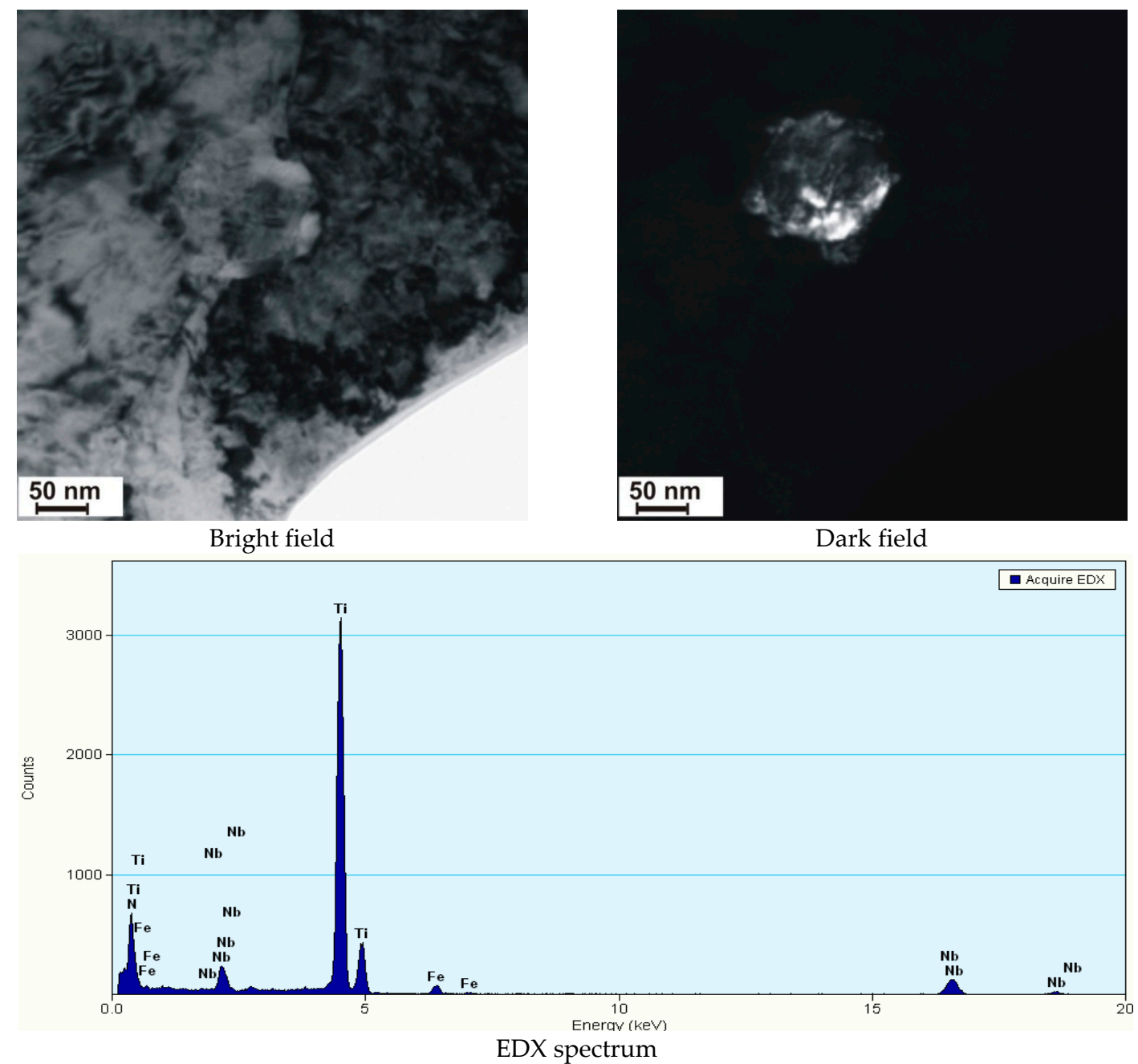

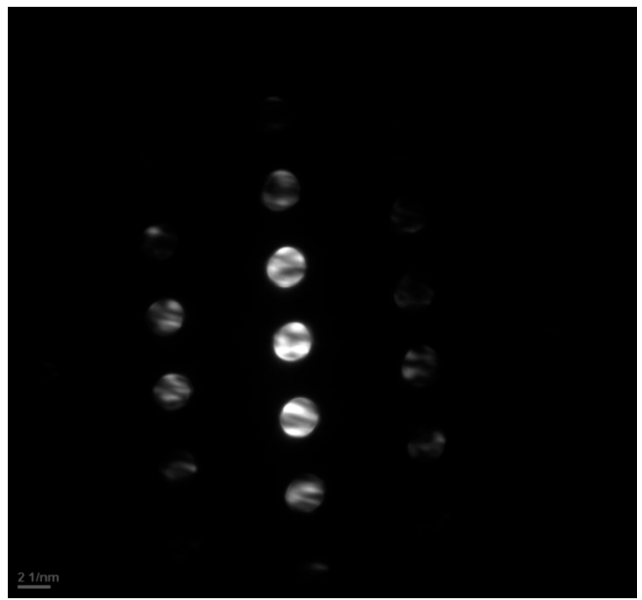

Diffraction pattern

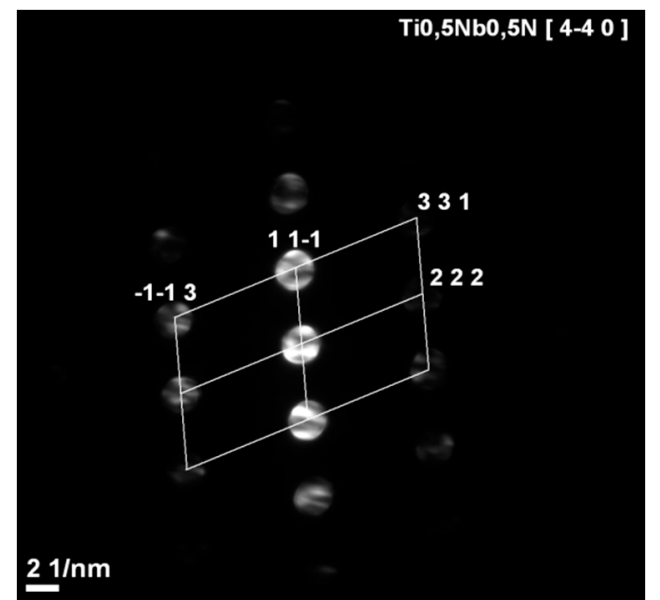

Diffraction pattern solution

Figure 13. Precipitation of nitride $(\mathrm{Ti}, \mathrm{Nb}) \mathrm{N}$ in the weld along with fine spherical precipitates and dislocations in the consolidating joint made of S700MC steel welded using a laser beam and a linear energy of $5 \mathrm{~kJ} / \mathrm{cm}$.

\section{Conclusions}

The analysis of the obtained experimental test results concerning high-yield-point steel S700MC subjected to the TMCP and of related joints justifies the formulation of the following conclusions: 
1. In cases of steel S700MC subjected to the TMCP (precipitation hardened by carbonitrides (Ti and $\mathrm{Nb}$ )), its weldability is not only affected by the carbon equivalent and phase transformations of austenite during cooling but primarily by the stability of hardening phases, the change in dispersion, and ageing processes. The steel S700MC was primarily affected by dispersive $(\mathrm{Ti}, \mathrm{Nb})(\mathrm{C}, \mathrm{N})$-type precipitates (a few $\mathrm{nm}$ in size) formed in the steel ferrite during cooling. The growth of recrystallised austenite grains in the steel was reduced by spherical $(\mathrm{Nb}, \mathrm{Ti}) \mathrm{C}$ and $(\mathrm{Ti}, \mathrm{Nb})(\mathrm{C}, \mathrm{N})$ carbide precipitates with diameters of between $10 \mathrm{~nm}$ and $50 \mathrm{~nm}$.

2. Steel S700MC was characterised by non-equilibrium bainitic-ferritic structure with numerous defects hardened through precipitation and solution hardening as well as through the strain and refining of grains. The process of welding led to changes in dispersion and disintegration of hardening phases, which, during cooling, reprecipitated in the HAZ and in the weld area, but in an uncontrolled manner. The increase of the base material content in the weld was accompanied by the increase in the concentration of hardening microalloying elements in the weld. The longer the time at which the material remained in the liquid state, the greater the amount of microalloying elements which could dissolve in the matrix and reprecipitate (during cooling) or remain in the solution.

3. In the case of the steel tested, the low content of carbon ( $0.056 \%$ by weight), primarily bounded by hardening elements $(\mathrm{Ti}, \mathrm{Nb})$, decreased its role in the hardening through the supersaturation of solid solution $\alpha$ and limited its effect during transformation $\gamma-\alpha$. Short cooling times results in martensite phase formation. However, the martensite formed after cooling is a low-carbon variety, i.e., it does not decrease the steel plasticity.

4. Low toughness, regardless of cooling time $t_{8 / 5}$, demonstrated that the developed CCT diagram under welding conditions of austenite phase transformations during the cooling of steel S700MC could not constitute the basis of its weldability assessment.

5. Because of the necessity of providing appropriate mechanical and plastic properties of welds made using the arc welding method, the filler metal should contain greater amounts of $\mathrm{Ni}, \mathrm{Cr}$, and Mo. The foregoing results in an increase in the carbon content in the weld to a value exceeding $0.5 \%$, which translates into the higher hardenability of the weld. Therefore, the welding process should be carried out with parameters ensuring the least possible melting of the base material.

6. The quality of welded joints made in steel S700MC is significantly affected by the welding method and welding linear energy (constant of the filler metal in the weld). The welding process should be performed so that the content of the filler metal in the weld (concentration of hardening microalloying elements having passed to the weld) is as low as possible.

Conflicts of Interest: The author declares no conflict of interest.

\section{References}

1. Xue, E.; Shan, Y.; Zheng, S.; Lou, S. Microstructural characteristic of low carbon microalloyed steels produced by termomechanical controlled process. Mater. Sci. Eng. 2006, 9, 285-287. [CrossRef]

2. Opiela, M. Thermodynamic analysis of the precipitation of carbonitrides in microalloyed steels. Mater. Technol. 2015, 49, 395-401. [CrossRef]

3. Medina, S.F.; Gomez, M.; Gomez, P. Effects of V and Nb on static recrystallization of austenite and precipitate size in microalloyed steels. J. Mater. Sci. 2010, 45, 5553-5557. [CrossRef]

4. Grajcar, A. Thermodynamic analysis of precipitation processes in Nb-Ti-microalloyed Si-Al TRIP steel. J. Therm. Anal. Calorim. 2014, 118, 1011-1020. [CrossRef]

5. Efron, L.I.; Morozov, D. Influence of rolling temperature on the austenite structure and properties of low-carbon microalloyed steel. Steel Transl. 2012, 42, 456-461. [CrossRef]

6. Lee, C.; Shin, H.; Park, K. Evaluation of high strength TMCP steel weld for use in cold regions. J. Constr. Steel Res. 2012, 74, 134-139. [CrossRef] 
7. Wang, S.H.; Chiang, C.C.; Chan, L.I. Effect of initial microstructure on the creep behaviour of TMCP EH36 and S490MC steels. Mater. Sci. Eng. A 2003, 344, 288-295. [CrossRef]

8. Shin, Y.T.; Kang, S.W.; Lee, H.W. Fracture characteristics of TMCP and QT steel weldments with respect to crack length. Mater. Sci. Eng. A 2006, 434, 365-371. [CrossRef]

9. Wang, G.R.; Lau, T.W.; Weatherly, G.G.; North, T.H. Weld thermal cycles and precipitation effects in Ti-V-containing HSLA steels. Metall. Trans. A 1989, 20, 93-100. [CrossRef]

10. Chang, K.; Lee, C.; Park, K.; Um, T. Experimental and numerical investigations on residual stresses in a multi-pass butt-welded high strength SM570-TMCP steel plate. Int. J. Steel Struct. 2011, 11, 315-324. [CrossRef]

11. Nishioka, K.; Ichikawa, K. Progress in termomechanical control of steel plates and their commercialization. Sci. Technol. Adv. Mater. 2012, 13, 1-20.

12. Hildebrand, J.; Werner, F. Change of structural condition of welded joints between high-strength fine-grained and structural steels. J. Civ. Eng. Manag. 2004, 10, 87-95. [CrossRef]

13. Jahazia, M.; Egbali, B. The influence of hot rolling parameters on the microstructure and mechanical properties of an ultra-high strength steel. J. Mater. Process. Technol. 2000, 103, 276-279. [CrossRef]

14. Kurc-Lisiecka, A.; Lisiecki, A. Laser welding of the new grade of advanced high-strength steel Domex 960. Mater. Technol. 2017, 51, 199-204. [CrossRef]

15. Kurc-Lisiecka, A.; Piwnik, J.; Lisiecki, A. Laser welding of new grade of advanced high strength steel STRENX 1100 MC. Arch. Metall. Mater. 2017, 62, 1651-1657. [CrossRef]

16. Portera, D.; Laukkanenb, A.; Nevasmaab, P.; Rahkab, K.; Wallin, K. Performance of TMCP steel with respect to mechanical properties after cold forming and post-forming heat treatment. Int. J. Press. Vessels Pip. 2004, 81, 867-877. [CrossRef]

17. Górka, J.; Janicki, D.; Fidali, M.; Jamrozik, W. Thermographic Assessment of the HAZ Properties and Structure of Thermomechanically Treated Steel. Int. J. Thermophys. 2017, 38, 183. [CrossRef]

18. Górka, J. Własności i Struktura Złączy Spawanych Stali Obrabianej Termomechanicznie o Wysokiej Granicy Plastyczności; Wydawnictwo Politechniki Śląskiej: Gliwice, Poland, 2013.

19. Górka, J. Microstructure and properties of the high-temperature (HAZ) of thermo-mechanically treated S700MC high-yield-strength steel. Mater. Technol. 2016, 50, 617-621. [CrossRef]

20. Górka, J. Welding Thermal Cycle-Triggered Precipitation Processes in Steel S700MC Subjected to the Thermo-Mechanical Control Processing. Arch. Metall. Mater. 2017, 62, 331-336. [CrossRef]

21. Górka, J. Analysis of simulated welding thermal cycles S700MC using a thermal imaging camera. In Advanced Material Research ISI Proceedings; Trans Tech Publications: Zürich, Switzerland, 2014; Volume 837, pp. 375-380.

22. Bajić, N.; Šijački-Žeravčić, V.; Rakin, M.; Kovačević, K. Effect of the welding mode and filler content on the structure of microalloyed $\mathrm{Nb} / \mathrm{Ti}$ steel weldments. Mater. Sci. 2010, 46, 124-133. [CrossRef]

23. Kim, Y.; Kwon, J.; Lee, H.; Jang, W. Effect of microstructure on fatigue crack propagation and S-N fatigue behaviours of TMCP steels with yield strengths of approximately $450 \mathrm{MPa}$. Metall. Mater. Trans. A 2011, 42, 986-999. [CrossRef]

24. Górka, J.; Stano, S. The structure and properties of filler metal-free laser beam welded joints in steel S700MC subjected to TMCP. In Laser Technology 2016: Progress and Applications of Lasers; International Society for Optics and Photonics: Bellingham, WA, USA, 2016; p. 101590K. [CrossRef]

25. Górka, J. Weldability of thermomechanically treated steels having a high yield point. Arch. Metall. Mater. 2015, 60, 469-475. [CrossRef]

26. Hirsch, P.B.; Howie, B.; Nicholson, A.M.; Pasheley, D.W.; Whelan, M.J. Electron Microscopy of Thin Crystals; Butterworths: London, UK, 1965.

27. Averbach, B.L.; Cohen, M. Transaction. AIME 1948, 176, 60-67.

28. Gladman, T. The Physical Metallurgy of Microalloyed Steels; The Institute of Materials, Cambridge University Press: Cambridge, UK, 1997.

29. Militzer, M. Computer simulation of microstructure evolution in low carbon sheet steels. ISIJ Int. 2007, 47, 1-15. [CrossRef]

30. Altuna, M.A.; Iza-Mendia, A.; Guitierrez, I. Precipitation strengthening by formation in ferrite of $\mathrm{Nb}$ carbides. In Proceedings of the 3rd International Conference on Thermomechanical Processing of Steels (TMP'2008), Padua, Italy, 10-12 September 2008; pp. 1-12. 
31. Hashimoto, S.; Ikeda, S.; Sugimoto, K.; Miyake, S. Effects of $\mathrm{Nb}$ and Mo addition to $0,2 \% \mathrm{C}-1,5 \% \mathrm{Mn}$ steel on mechanical properties of hot rolled TRIP-aided steel sheets. ISIJ Int. 2004, 44, 1590-1598. [CrossRef]

32. Wang, X.D.; Huang, B.X.; Wang, L.; Rong, Y.H. Microstructure and mechanical properties of microalloyed high-strength transformation-induced plasticity steels. Metall. Mater. Trans. A 2008, 39, 1-7. [CrossRef]

33. Timokhaina, I.B.; Hodgson, P.D.; Pereloma, E.V. Effect of microstructure on the stability of retained austenite in transformation-induced-plasticity steels. Metall. Mater. Trans. A 2004, 35, 2331-2341. [CrossRef]

34. Opiela, M. Elaboration of thermomechanical treatment conditions of Ti-V and Ti-Nb-V microalloyed forging steels. Arch. Metall. Mater. 2014, 59, 1181-1188. [CrossRef]

35. Grajcar, A.; Różański, M.; Kamińska, M.; Grzegorczyk, B. Effect of gas atmosphere on the non-metallic inclusions in laser-welded TRIP steel with $\mathrm{Al}$ and Si additions. Mater. Technol. 2016, 50, 945-950. [CrossRef]

36. Żuk, M.; Górka, J.; Czupryński, A.; Adamiak, M. Properties and structure of the weld joints of quench and tempered 4330V steel. Metalurgija 2016, 55, 613-616.

37. Kang, S.; Tuling, A.; Mintz, B. The hot ductility of $\mathrm{Nb}$ containing TRIP steels. In Proceedings of the 3rd International Conference on Thermomechanical Processing of Steels (TMP'2008), Padua, Italy, 10-12 September 2008; pp. 1-10.

38. Grajcar, A. Struktura Stali C-Mn-Si-Al Kształtowana z Udziałem Przemiany Martenzytycznej Indukowanej Odkształceniem Plastycznym; Wydawnictwo Politechniki Śląskiej: Gliwice, Poland, 2009.

39. Janicki, D. Laser cladding of Inconel 625-based composite coatings reinforced by porous chromium carbide particles. Opt. Laser Technol. 2017, 94, 6-14. [CrossRef]

40. Yasuharu, S.; Osamu, M.; Hiroshi, T. Mechanical properties and retained austenite in intercritically heat-treated bainite-transformed steel and their variation with $\mathrm{Si}$ and $\mathrm{Mn}$ additions. Metall. Trans. A 1991, 22, 489-498.

41. Rodriguesa, P.; Perelomab, E.; Santos, C. Mechanical properties of an HSLA bainitic steel subjected to controlled rolling with accelerated cooling. Mater. Sci. Eng. A 2000, 283, 136-143. [CrossRef]

42. Bhadeshia, H.K. Bainite in Steels, 2nd ed.; Institute of Materials, Minerals and Mining: Cambridge, UK, 2001; pp. 265-268.

(C) 2018 by the author. Licensee MDPI, Basel, Switzerland. This article is an open access article distributed under the terms and conditions of the Creative Commons Attribution (CC BY) license (http:/ / creativecommons.org/licenses/by/4.0/). 